\title{
Population structure of daytime surface swarms of Nyctiphanes simplex (Crustacea: Euphausiacea) in the Gulf of California, Mexico
}

\author{
D. Gendron \\ Departamento de Plancton, Centro Interdisciplinario de Ciencias Marinas (CICIMAR-IPN), Apdo Postal 592, La Paz, \\ B.C.S., Mexico 23000
}

\begin{abstract}
Daytime surface swarms of the euphausiid Nyctiphanes simplex were observed during 9 spring seasons between 1984 and 1992 along the east coast of Baja California in the southwest part of the Gulf of California. Analyses of sex and maturity of surface patch samples showed that $57 \%$ of the euphausiids were in breeding condition; males possessed developed spermatophores while females were carrying eggs and metanauplii. Sex ratios of female: male were between $1: 1$ and $2: 1$ Swarm samples contained high numbers of eggs and metanauplii. Both results suggest that this swarming phenomenon is related to reproductive activity. However, analysis of one particular swarm sample of $N$. simplex showed that only $8 \%$ were in breeding condition. The highest biomass found was $32.6 \mathrm{~g}$ wet $w t \mathrm{~m}^{-3}$, which is correlated with the high trophic activity observed in the sample area.
\end{abstract}

\section{INTRODUCTION}

Daytime surface swarming of euphausiids is a spontaneous phenomenon, mostly detected by red surface patches and often accompanied by numerous predators like birds, whales and fishes. Mauchline (1980) listed 18 euphausiids, predominantly distributed in high latitudes, known to form such aggregations at the surface. Nyctiphanes simplex (Hansen, 1912) was mentioned as a species that probably forms these aggregations, although no confirmation had then been published.

Steinbeck \& Ricketts (1941) were the first to observe such swarming in the Gulf of California and they described the water off Punta San Marcial $\left(25^{\circ} 30^{\prime} \mathrm{N}\right.$, $111^{\circ} 03^{\prime} \mathrm{W}$ ) (cited by Brinton et al. 1986) as 'soupy' with Nyctiphanes simplex. Around Isla del Carmen $\left(26^{\circ} \mathrm{N}\right.$, $111^{\circ} 20^{\prime} \mathrm{W}$ ), Sears (1987) detected daytime surface swarms of $N$. simplex and noted their association with surface feeding activity of the blue whale Balaenoptera musculus.

Nyctiphanes simplex is the most abundant and widespread euphausiid in the Gulf of California, with a maximum abundance and reproductive period occur- ring between February and June (Brinton \& Townsend 1980). This neritic species remains above $100 \mathrm{~m}$ in nearshore localities in the Gulf, but there is a suggestion that it migrates vertically to greater depths (Brinton et al. 1986). The females carry their eggs externally in sacs until the free swimming metanauplii hatch.

Komaki (1967) proposed 4 hypotheses to explain the swarming phenomenon: (1) euphausiids congregate at the surface to feed; (2) or to escape predators; (3) they are passively transported to the surface by physical processes or are feeding on organisms that are passively brought to the surface, or (4) they actively search out the surface for some factor related to reproduction.

The present work involved observations of euphausiid surface swarms during February, March and April over a period of $9 \mathrm{yr}$ in the southwest part of the Gulf of California. The aim of this study was to examine the occurrence of the Nyctiphanes simplex daytime surface swarms, to describe the population structure of this phenomenon, and to examine the possible functions of swarming in relation to the hypotheses proposed by Komaki (1967). 


\section{MATERIALS AND METHODS}

During February, March, and April 1984 to 1989, observations and sampling of daytime surface swarms of euphausiids were carried out in conjunction with marine mammal observations by the Mingan Island Cetacean Study group. No sampling was conducted during 1985, 1986 and 1991 and no swarms were observed in 1987 and 1992. The work was done from $22 \mathrm{ft}(6.7 \mathrm{~m})$ fiberglass boats (locally called pangas) in the Isla del Carmen area (Fig. 1). During the same months of 1988 to 1992, observations and sampling were also made on board boats of the tourist company Baja Expeditions, which covered the Bahía de La Paz (the area between the southern tip of Isla San José and the southern end of Isla Espiritu Santu) north to Isla del Carmen (Fig. 1). Positions were obtained from the boat or panga with $7 \times 50$ compass binoculars using the triangulation method. Seven swarms were sampled

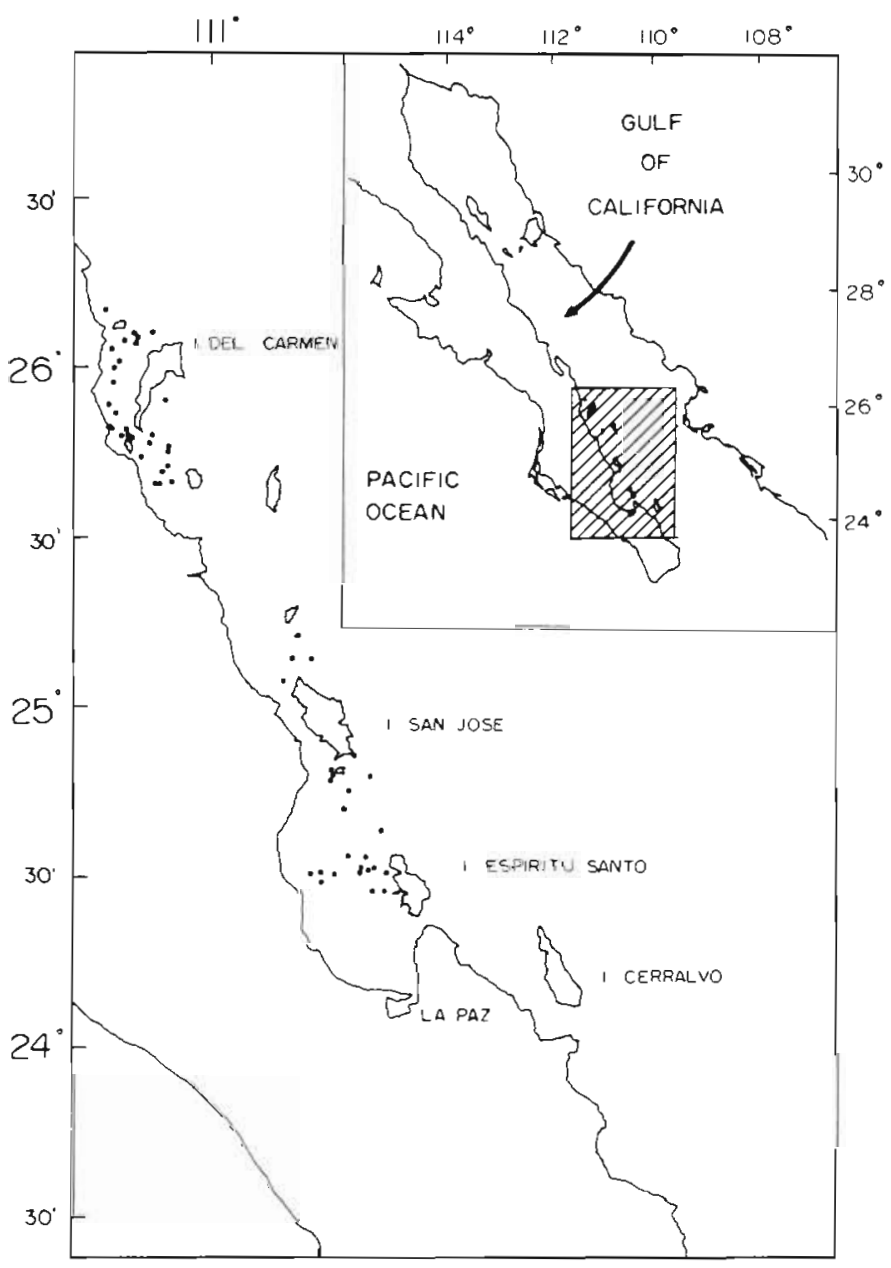

Fig. 1. Study area showing positions of Nyctiphanes simplex swarms observed during the 1984 to 1991 spring periods in the southwest part of the Gulf of California using either a glass container of ca 1 I dipped at the surface or a CalCoFi type net (mouth diameter $=60 \mathrm{~cm}$, mesh $=500 \mu \mathrm{m}$ ) with a flowmeter (TSK) (Table 1). which was pulled at the surface for $3 \mathrm{~min}$ at ca 2 knots. Samples were preserved in $4 \%$ formaldehyde and seawater, buffered with sodium borate. The biomass was measured using the displaced volume method described by Smith \& Richardson (1979). Conversion to $\mathrm{g}$ wet wt $\mathrm{m}^{-3}$ was calculated using Weibe et al. (1975). Surface temperature of water at the sampling sites was registered only for the Bahía de La Paz area.

Swarm samples containing less than $50 \mathrm{ml}$ of displaced volume were examined in total. Larger samples were divided using a Folsom plankton splitter. Individuals were identified to life stage level using the key provided in Boden (1951) and a micrometric binocular microscope. Mature females were categorized as ovigerous with egg sacs containing eggs and/or metanauplii or with spent egg sacs still attached.

Total length (from the base of the eye to the end of the carapace) of 71 ovigerous females were compared with the number of eggs and metanauplii carried per ovigerous female.

\section{RESULTS}

Surface swarms of Nyctiphanes simplex were observed in February, March and April from 1984 to 1992 in the southwest part of the Gulf of California (Fig. 1), though most were detected during mid-March. Swarms were located by the presence of whales, marine birds or turbulence at the water surface. During 1987 no swarm was observed. Swarming occurred between $09: 00$ and 17:00 $\mathrm{h}$, with cloud cover ranging from 0 to 9 tenths, in sea states of 0 to 3 on the 12-point Beaufort scale. Surface temperatures of water at the sampling sites in the Bahía de La Paz area were 20 to $21^{\circ} \mathrm{C}$.

The size of the swarms, which were estimated visually, varied from small patches with euphausiids 'parallel swimming' to dense 'boiling' patches of ca 5 to $30 \mathrm{~m}$ in diameter (we found that swarms were roughly round). Euphausiid biomass ranged from 0.07 to $32.6 \mathrm{~g}$ wet wt $\mathrm{m}^{-3}$.

Analyses of sex and maturity of 1450 individuals from 6 swarm samples (Fig. 2) showed that the sex ratio of female:male ranged from $1: 1$ to $2: 1$ and that $57 \%$ of the euphausiids were in breeding condition $72 \%$ of the males with developed spermatophores and $43 \%$ of the females carrying eggs, metanauplii or spent egg sacs). Only 3 females had spermatophores attached to the thelycum. In the 29 March 1989 sample (Fig. 2d), only $8 \%$ of the individuals were in breeding condition. In the other 5 samples, the range was 55 to $78 \%$. 
Table 1. Dates, locations and sampling methods of Nyctiphanes simplex surface swarm samples

\begin{tabular}{|c|c|c|c|c|c|}
\hline \multirow{2}{*}{ Year } & \multirow{2}{*}{ Date } & \multirow{2}{*}{$\begin{array}{l}\text { Time } \\
\text { (h) }\end{array}$} & \multicolumn{2}{|c|}{ Location } & \multirow{2}{*}{ Sampling method } \\
\hline & & & Lat. N & Long. W & \\
\hline 1984 & $04 \mathrm{Apr}$ & a & $26^{\circ} 03^{\prime}$ & $111^{\circ} 19^{\prime}$ & Glass jar \\
\hline 1987 & - & - & - & - & - \\
\hline 1988 & $21 \mathrm{Mar}$ & $18: 00$ & $24^{\circ} 48^{\prime}$ & $110^{\circ} 35^{\prime}$ & Surface sample \\
\hline 1988 & $23 \mathrm{Mar}$ & $17: 00$ & $24^{\circ} 15^{\prime}$ & $110^{\circ} 31^{\prime}$ & Surface sample \\
\hline 1989 & $28 \mathrm{Mar}$ & $11: 30$ & $24^{\circ} 27^{\prime}$ & $110^{\circ} 28^{\prime}$ & Surface sample \\
\hline 1989 & $29 \mathrm{Mar}$ & $16: 42$ & $24^{\circ} 37^{\prime}$ & $110^{\circ} 28^{\prime}$ & Surface sample \\
\hline 1990 & $04 \mathrm{Mar}$ & $16: 30$ & $26^{\circ} 03^{\prime}$ & $111^{\circ} 12^{\prime}$ & Glass jar \\
\hline 1990 & $10 \mathrm{Mar}$ & $15: 25$ & $25^{\circ} 52^{\prime}$ & $111^{\circ} 18^{\prime}$ & Surface sample \\
\hline 1992 & - & - & - & - & - \\
\hline
\end{tabular}

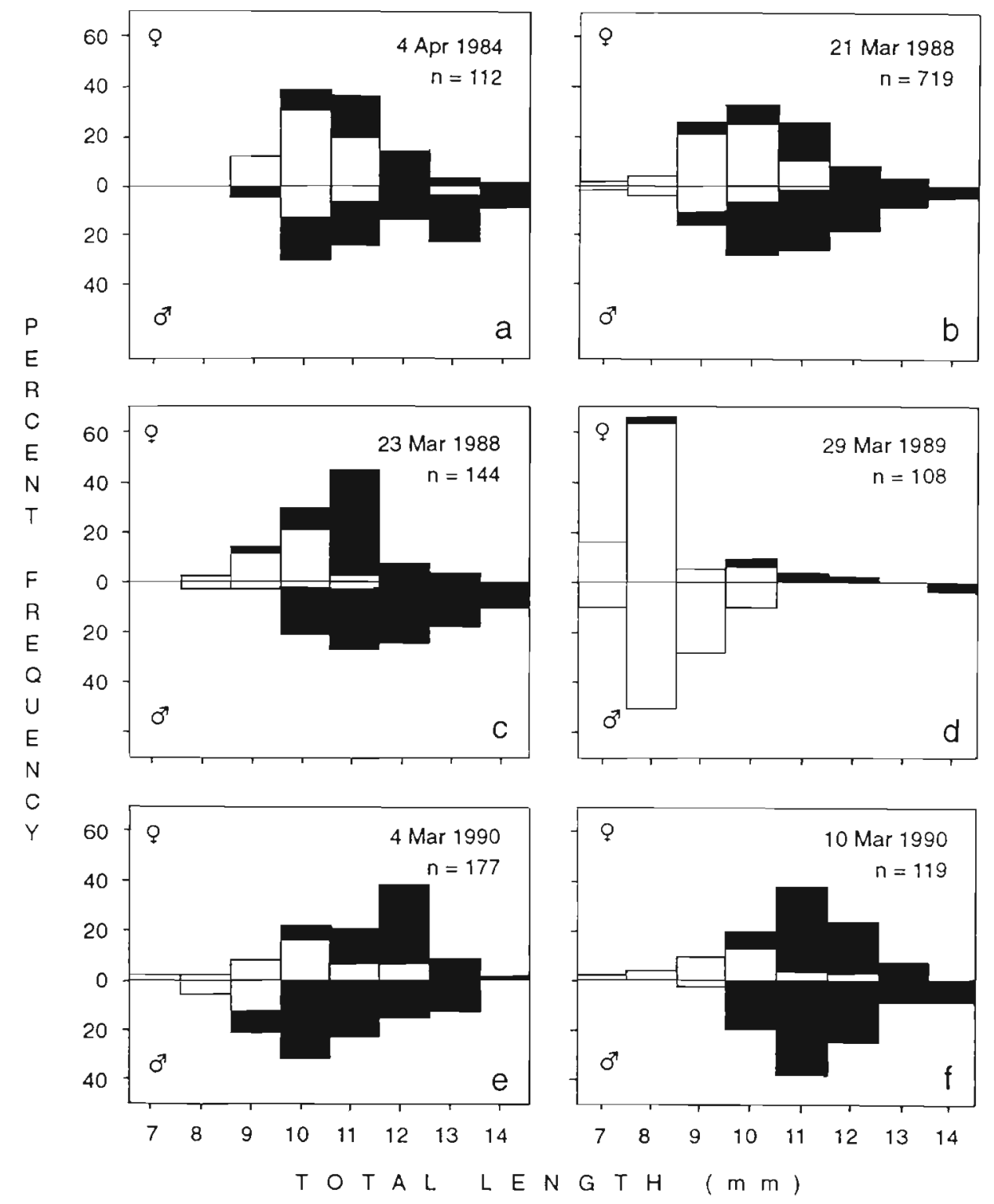

Fig. 2. Nyctiphaens simplex. Length frequency histograms of the 6 swarm samples. Open bars: females without egg sac, males without spermatophores; solid bars: females carrying eggs or metanauplii or spent egg sac, males with spermatophores 


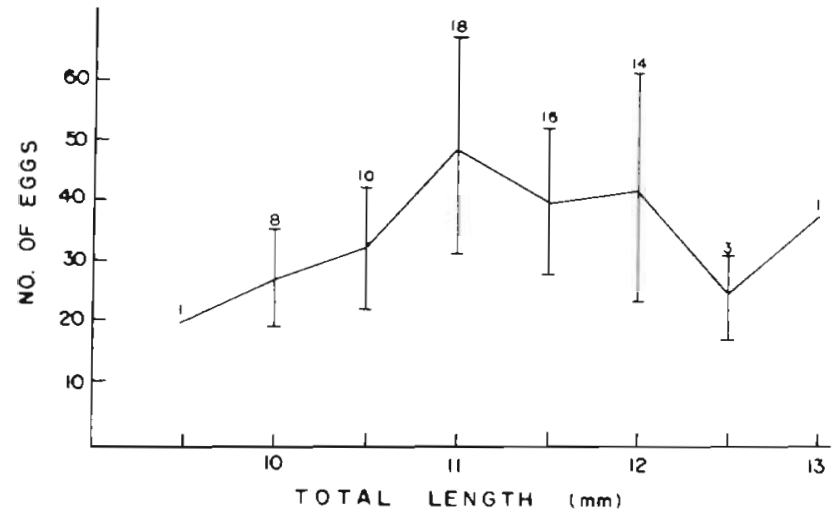

Fig. 3. Nyctiphanes simplex. Range and mean number of eggs and/or metanauplii per egg sac in relation to body length in females. Number above bar indicates individuals examined

In all swarm samples, Nyctiphanes simplex eggs, metanauplii, and nauplii were numerous. The egg presence in the sample may have been caused by manipulation from the net to sample container. On 29 March 1989, the surface swarm sampled was entirely composed of calyptopis and furcilia with a percent frequency of 96 and $4 \%$.

The mean number of eggs and/or metanauplii per egg sac ranged from 20 to 49 and the standard deviation within each length group was as much as 18.4 (at $11 \mathrm{~mm}$ length) (Fig. 3). The mean number of eggs and/or metanauplii increased until the females were $11 \mathrm{~mm}$. Thereafter, the number tends to decrease, as Brinton (1976) found in Euphausia pacifica.

\section{DISCUSSION}

The high proportion in the swarms of (1) adults in breeding condition (males with developed spermatophores, ovigerous females), (2) the presence of so many eggs and metanauplii in the samples, and (3) the presence of a larval swarm, all suggest that daytime surface swarming of Nyctiphanes simplex is mainly related to reproduction. The breeding season of this dominant euphausiid species in the Gulf of California is from February to June, producing more than $80 \%$ of the calyptopis in the mid-and southern Gulf (Brinton \& Townsend 1980). This coincides with the swarming season and agrees with the findings of Endo (1984) for Euphausia pacifica in Japanese waters, of Nicol (1984) for Meganyctiphanes norvegica in the Bay of Fundy, Canada, of $O^{\prime}$ Brien et al. (1986) for $N$. australis in the southeast Tasmanian region, and of Smith \& Adams (1988) for Tysanoessa spinifera in the Gulf of Farallones, California. All these authors concluded that swarming is related to reproduction.
Surface swarming could be related to reproduction in different ways as had been discussed by some of the authors mentioned above: (1) for more effective transfer of spermatophores; (2) for release of eggs at the surface (for species that do not carry eggs sacs); or (3) for maturation of sexual product in adults and or incubation of eggs in warm surface layers.

The presence of ovigerous females carrying eggs and/or metanauplii, the great quantity of both eggs and metanauplii in the samples and the occurrence of a larval swarm suggest that the release of metanauplii is an important factor in this swarming phenomenon. As discussed in Nicol (1984), egg release at the surface by euphausiid species which do not carry eggs in sacs would provide more time for eggs to develop and hatch before reaching the sea floor.

In the Nyctiphanes simplex case, the release of free swimming metanauplii at the surface could be beneficial for other reasons. Ovigerous females (55 to $78 \%$ ) carried both eggs and metanauplii in their sacs. This suggests that the hypothesis about incubation of the egg sacs in warm surface layers may be related to the daytime surface swarming of $N$. simplex. On the other hand, the release of metanauplii would appear to take place in areas of high primary productivity, yielding adequate food during larval development in the phytoplankton-rich surface waters (Mauchline 1980). In fact, phytoplankton studies have shown that the highest cell densities occur in March in the Gulf of California (Gilbert \& Allen 1943), including Bahía de La Paz (García-Pamanes 1981).

The high proportion of adults in breeding condition and the low proportion of juveniles (except for the sample of 29 March 1989) support the hypothesis discussed in Nicol (1984). His hypothesis that segregation of adults (upper layer) from juveniles (lower layer) may facilitate transfer of spermatophores is plausible here since $72 \%$ of males possessed developed spermatophores. However, only 3 females had spermatophores attached to the thelycum. The absence of females with spermatophores attached to the thelycum has been observed in other species and could be explained by the rapid discharge of the sperm either during or immediately following copulation (Costanzo \& Guglielmo 1979).

The hypothesis related to physical transport and feeding activity cannot be neglected since other zooplankton groups were observed in some samples, including microphytoplankton and one other euphausiid, Nematocelis difficilis, which is usually distributed between 50 and $200 \mathrm{~m}$ both during the day and at night (Brinton 1967. Brinton et al. 1986) and is not known to perform surface swarming (Mauchline 1980).

The 29 March 1989 sample contained smaller individuals and a low proportion of adults in breeding 
condition (8\%). Non-reproductive surface swarms of euphausiids have been reported in the Bay of Fundy by Brown et al. (1979), who concluded that these swarms were related to turbulence where strong tidal streams ran up against steep underwater ledges, bringing cool subsurface water and also copepods to the surface.

The sites where swarms of Nyctiphanes simplex have been detected along the western side of the Gulf of California are characterized by steep slopes and limited shallow waters. Brinton \& Townsend (1980) noted that the many islands, particularly along the western Gulf, must provide additional coastline, which thus augments the extent of mixing processes and upwelling. Although no intense oceanographic study has been done in this part of the Gulf of California, it is known that the dominant north wind during the spring period (February to April) is associated with a north to south current which follows the west side of the Gulf (Rosa-Cota 1977). The effect of the north-south current along with out-going tidal current could possibly provoke accumulation of euphausiids along the wall formed by the steep slope, especially at the end of the funnel between Isla del Carmen or Isla San José and the peninsula. More oceanographic studies on currents need to be done to better understand this phenomenon.

Nyctiphanes australis has been described as performing not only surface swarming, but also stranding and 'matting' behavior (O'Brien et al. 1986). It is interesting to note that no such behavior was observed for $N$. simplex in the study area. There is not, however, much shallow water along both the peninsula and islands as compared with the area where this behavior had been observed.

The presence of mammal, bird, and fish predators was noted at the sampling sites or close to them. However, some swarms have been observed without the presence of any visible predator. We observed that very dense swarms were associated with numerous predators, thus suggesting that the feeding behavior of the predators may concentrate the swarm. In those observations, euphausiids were seen escaping from manta rays and whales by jumping out of the water, which is commonly called 'boiling water'.

The highest density found in the 21 March 1988 sample ( $32.6 \mathrm{~g}$ wet $\mathrm{wt} \mathrm{m}^{-3}$ ) exceeds the normal range for euphausiid biomass encountered in the Gulf at this time of year (Brinton \& Townsend 1980, Gendron 1990). The 21 March 1988 biomass corresponds to daytime surface samples taken in the Gulf of St. Lawrence, Canada (Sameoto 1983), a whale feeding ground, and it is greater than the biomass found in the Tysanoessa spinifera swarms in the Monterey, California, USA, area during 1986, where blue whales were surface feeding (Schoenherr 1988). It is almost twice what Brodie et al. (1978) estimated for the minimum daily requirements of a fin whale $\left(17.9 \mathrm{~g} \mathrm{~m}^{-3}\right)$. Sameoto (1983) suggested that density in daytime surface swarms may be a reflection of the normal abundance of euphausiids in the water column. If this is the case, the high biomass found in surface swarm may suggest that Nyciphanes simplex is an important food supply in the southwest Gulf of California during spring periods.

All the observations were combined with marine mammal observations. Blue whales Balaenoptera musculus, fin whales $B$. physalus and Bryde's whales $B$. edeni were frequently seen feeding on these swarms. As noted by Mauchline (1980), aggregations are known to occur in at least 19 of the 27 euphausiid species listed as the food of whales. Nyctiphanes simplex has been reported as food of fin whales (Antezana 1970) and blue whales (Sears 1987) and can now be added to this list.

The manta ray Mobula lucasana is another important predator on Nyctiphanes simplex swarms. The ray's abundance is often associated with the presence of blue whales in this part of the Gulf. The white fish Caulolatilus princeps feeds principally on $N$. simplex in May to July in the Bahía de La Paz area (CaraveoPatiño 1991). Its habit of feeding on the bottom shows that $N$. simplex is distributed, at least part of the day, near the bottom. This agrees with Mauchline (1980), who noted that $N$. simplex possibly fed on detritus at the bottom. The reason for the absence of $N$. simplex in the stomachs of white fish in February, March and April may be that in the swarming period adults of $N$ simplex are distributed throughout the water column up to the surface, thus being unavailable for the white fish.

It is of interest to note that during both 1987 and 1992, no surface swarms were observed in the study area. The year 1987 was positively correlated with increased surface temperature of water related to El Niño/Southern Oscillation (ENSO) events 1986-1987 (McPhander et al. 1990) and it is believed that another ENSO event is taking place during 1992.

Although this swarming phenomenon has not been reported in other parts of the Gulf of California, a swarm of Nyctiphanes simplex was observed on a cruise of the Scripps research vessel 'Alexi Agassa' off the Pacific coast of Baja California on 15 June 1965 at $27^{\circ} 40^{\prime} \mathrm{N}, 115^{\circ} 08^{\prime} \mathrm{W}$. A sample is in the Plankton Collection at the Scripps Institute of Oceanography ${ }^{1}$. It is interesting to note that Carl Hubbs observed, $2 \mathrm{~d}$ later, many blue whales in same area ${ }^{2}$. Swarms may thus occur much more widely than the present study shows.

\footnotetext{
${ }^{1}$ Scripps Institution of Oceanography Archives. 1965. E Golfo, Plankton Collection

${ }^{2}$ Hubbs Collection, Box 53, in the Scripps Archives
} 
Acknowledgements. The author thanks Richard Sears and Martine Bérubé of the Mingan Island Cetacean Study for their data on surface swarm observations during the 1984-1989 spring periods and the 1984 sample; Tim Means of Baja Expeditions for using their vessels as a platform of observation and José Lozano, captain of the 'Don José', for help with the observations and sampling; and Tesuo Matsui for searching in the Scripps Institution of Oceanography Archives for the swarm observed along the west coast of Baja California. This project is part of a Master's thesis which was funded by the Mexican Government (Secretaria de Relaciones Exteriores). Finally I thank Drs Edward Brinton of the Scripps Institution of Oceanography, Peter Whitehead (deceased, 7 May 1992) of Centro de Investigaciones Biológica de Baja California Sur and Ellis Glazier of Centro Interdisciplinario de Ciencias Marinas for reviewing this article.

\section{LITERATURE CITED}

Antezana, T. J. (1970). Eufaúsidos de la costa de Chile. Su rol en la economia del mar. Rev. Biol. mar. Valparaíso 14(2): $19-27$

Boden, B. P. (1951). The egg and larval stages of Nyctiphanes simplex, a euphausiid crustacean from California. Proc. zool. Soc. Lond. 121: 26-48

Brinton, E. (1967). Vertical migration and avoidance capability of euphausiids in the California Current. Limnol. Oceanogr. 12: 451-483

Brinton, E. (1976). Population biology of Euphausia pacifica of Southern California. Fish. Bull. U.S. 74: 733-762

Brinton, E., Townsend, A. W. (1980). Euphausiids in the Gulf of California, the 1957 cruises. Rep. Calif. coop. oceanic Fish Invest. 21: 211-236

Brinton, E., Fleminger, A., Siegel-Caussey, D. (1986). The temperate and tropical planktonic biotas of the Gulf of California. Rep. Calif. coop. oceanic. Fish Invest. 27: 221-236

Brodie, P. F., Sameoto, D. D., Shelton, R. W. (1978). Population densities of euphausiids of Nova Scotia as indicated by net samples, whale stomach contents, and sonar. Limnol. Oceanogr. 23: 1264-1267

Brown, R. G. B., Baker, S. P., Gaskin. D. E. (1979). Daytime surface swarming by Meganyctiphanes norvegica (M. Sars) (Crustacea, Euphausiacea) off Brier Island, Bay of Fundy. Can. J. Zool, 57: 2285-2291

Caraveo-Patiño, J. (1991). Hábitos alimenticios de la pierna (Caulolatilus princeps) (Jenyns, 1842) en la Bahía de La Paz. B.C.S. México. Degree thesis, Universidad Autónoma de Baja California Sur, La Paz

Costanzo, G. Guglielmo, L. (1979). On the transfer of spermatophores in preserved specimens of Meganyctiphanes norvegica (M. Sars) (Crustacea; Euphausiacea). Atti Soc. pelorit. Sci. fis. mat. nat. 25(1): 103-109
Endo, Y (1984). Daytime surface swarming of Euphausia pacifica (Crustacea: Euphausiacea) in the Sanriku coastal waters of northeastern Japan. Mar. Biol. 79: 269-276

García-Pamanes, J. (1981). El fitoplancton de la porción oriental de la Bahía de La Paz, B.C.S. durante primavera y verano. In: Gómez-Aguirres, S. (ed.) Proc. 7th Simposio Latinoamericano sobre Oceanografía Biológica. Acapulco, México, p. 201-219

Gendron, D. (1990). Relación entre la abundancia de eufaúsidos y de ballenas azules (Balaenoptera musculus) en el Golfo de California. M.Sc. thesis, Centro Interdisciplinario de Ciencias Marinas, Instituto Politécnico Nacional, La Paz

Gilbert, J. Y., Allen, W. E. (1943). The phytoplankton of the Gulf of California obtained by the 'E. W. Scripps' in 1939-1940. J. mar. Res. 5(2): 89-110

Komaki, $Y$ (1967). On the surface swarming of euphausiid crustaceans. Pacif. Sci. 21: 433-448

Mauchline, J. (1980). The biology of mysids and euphausiids. Adv. mar. Biol. 18: 1-681

McPhander, M. J., Hayes, S. P., Mangum, L. J. (1990). Variability in the Western Equatorial Pacific Ocean during the 1986-1987 El Nin̄o/ Southern Oscillation Event. J. phys. Oceanogr. 20: 190-208

Nicol, S. (1984). Population structure of daytime surface swarms of the euphausiid Meganyctiphanes norvegica in the Bay of Fundy. Mar. Ecol. Prog. Ser 18: 241-251

O'Brien, D. P., Ritz, D. A., Kirkwood, R. J. (1986). Stranding and matting behavior in Nyctiphanes australis (Euphausidae: Crustacea). Mar. Biol. 93: 465-473

Rosa-Cota, A. (1977). Corrientes geostróficas en el Golfo de California en la superficie y a 200 metros, durante las estaciones de invierno y verano. Rep. Calif. coop. oceanic. Fish Invest. 19: 89-106

Sameoto, D. D. (1983). Euphausiid distribution in acoustic scattering layers and its significance to surface swarms. J. Plankton Res. 5(2): 129-143

Schoenherr, J. R. (1988). Blue whales feeding on high concentrations of euphausiids around Monterey submarine canyon. M.Sc. thesis, Moss Landing, San Jose State University, California

Sears, R. (1987). The photographic identification of individual blue whale (Balaenoptera musculus) in the Sea of Cortez. Cetus 7(1): $14-17$

Smith, P. E., Richardson, S. L. (1979). Técnicas modelo para prospecciones de huevos y larvas de peces pelágicos. FIR/T175 (Es) FAO, Fish tech. Pap. 175: 1-107

Smith, S., Adams, P. B. (1988). Daytime surface swarms of Tysanoessa spinifera in the Gulf of Farallones, California. Bull. mar. Sci. 42(1): 76-84

Steinbeck, J., Ricketts, E. F. (1941). The Sea of Cortez. Viking Press, New York

Weibe, P. H., Boyd, S., Cox, J. L. (1975). Relationship between zooplankton displacement volume, wet weight and carbon. Fish. Bull. U.S. 73(4): 777-786

Manuscript first received: August 5, 1991

Revised version accepted: July 28, 1992 